\section{Did Taupo's eruption enhance European sunsets?}

\begin{abstract}
A NEW precise date of $186 \mathrm{AD}$ has been postulated $^{1}$ for a series of large rhyolitic plinian and pyroclastic flow eruptions at Taupo, New Zealand. Evidence came from Chinese and Roman records of a brilliant red Sun and Moon and of clouds dimming the Sun. Although the Taupo eruption was one of the largest within the period AD 100-200, there is evidence that this eruption did not disperse enough fine tephra into the atmosphere, let alone into the Northern Hemisphere, to produce the phenomena described.
\end{abstract}

Evidence suggesting that the Taupo eruption and the recorded Sun phenomena are unrelated is as follows: (1) The Chinese excerpt ${ }^{1}$ describes the Sun and Moon themselves as being "red as blood" when they rose and set and do not describe glow phenomena or "sunset colours". Direct red colouration of the Sun followed the eruptions of Krakatau 1883 and Bali 1963 and was generally restricted to near the volcanic source and to areas at about the same latitude ${ }^{2}$. Red colouration of the Sun is due to very small particles $(<0.5 \mu \mathrm{m})$ or smoke haze scattering short-wavelength light. Thus the Chinese record is more consistent with atmospheric dust or smoke haze in the lower troposphere than higher-altitude volcanic dust. Similarly, one Roman account of a widespread red colour is also more consistent with atmospheric dust or smoke.

(2) Although the Taupo eruptions were large, they were not as exceptional as implied by Walker ${ }^{3}$. I have recalculated the volume of the "Taupo pumice fall deposit" to be $14 \mathrm{~km}^{3}$, in contrast to the $24 \mathrm{~km}^{3}$ calculated by Walker ${ }^{3}$, who claimed that $\sim 70 \%$ of the volume $\left(16 \mathrm{~km}^{3}\right)$ was sub- $2 \mathrm{~mm}$ particles that had all fallen beyond land: this is excessive, as it is based on an incorrect assumption of crystal liberation and fine ash generation in the plinian eruption column ${ }^{3}$. Furthermore, if $16 \mathrm{~km}^{3}$ of fine ash had been generated, then a more extensive distribution of this tephra should have been found in offshore cores ${ }^{4-6}$. I deduce a more realistic figure of $20 \%$ of fine ash. (3) The height reached by the eruption column is controlled by convective strength and heat output, not total eruption volume ${ }^{7}$. The total column density can never be greater than surrounding atmosphere density, as with zero shear strength the column would then collapse. Thus $16 \mathrm{~km}^{3}$ of fine ash could not rise beyond $50-55 \mathrm{~km}$ (ref. 7) and no large quantities could reach the mesosphere. At these heights, particles would fall to lower elevations within a few weeks ${ }^{2}$, before the widespread dispersal claimed by Wilson $e t$ $a l .{ }^{1}$ could occur. Thus Lamb's deduction ${ }^{2}$ of material reaching the Northern Hemisphere only if erupted north of $20^{\circ} \mathrm{S}$ latitude is considered valid. For comparison, an eruption on Bali $\left(8.5^{\circ} \mathrm{S}\right)$ in March. 1963 produced an observed column up to $50 \mathrm{~km}$ high which had fallen to $31-35 \mathrm{~km}$ by November 1963 , when 'sunset phenomena' were observed from Australia to England ${ }^{2}$. Particles with diameters of $\sim 1 \mu \mathrm{m}$ were being concentrated in the equatorial region at 20 $22 \mathrm{~km}$ up to April $1964^{8}$. Thus the Taupo material would also be expected to fall rapidly from $\sim 55 \mathrm{~km}$ height to the lower stratosphere and, being erupted from $39^{\circ} \mathrm{S}$, would spread over the Southern Hemisphere. As large quantities of fine ash could not have reached the Northern Hemisphere, the chances of this material causing red Sun phenomena witnessed by Europeans are slight.

(4) Confirmation of the Taupo date could be sought in polar ice cores ${ }^{1}$. Acidity profiles in the Greenland ice sheet ${ }^{9}$ are incomplete for between AD 0 and 500. In the Greenland ice cores, an earlier and larger eruption from Taupo (Waimihia Tephra, $1640 \pm 130 \mathrm{BC})^{3,10}$ has not been noted, so the Taupo event may not be represented either. Consequently, migration of volcanic acids and hence microparticles into the Northern Hemisphere following the Taupo eruption is doubtful. (5) Finally, and most importantly, Wilson et al quoted a date for only one of the Roman accounts (AD 186) and a range of AD 168-189 for the Chinese record. They did not attempt to substantiate that the three accounts were describing the same event. Thus the ancient writers were probably describing different events, possibly the results of dust-storms or fires.

\section{P. C. Froggatt}

Geology Department,

Victoria University,

Wellington, New Zealand

1. Wilson, C. J. N., Ambraseys, N. N., Bradley, J. \& Walker, G. P. L. Nature 288, 252-253 (1980)

. Lamb, H. H. Phil. Trans, R. Soc. A226, 425-533 (1970). 3. Walker, G. P. L. J. volcan. geotherm. Res. 8, 69-94 (1980) 4. Lewis, K. B. \& Kohn, B. P. N.Z. J. Geol. Geophys. 16 439-454 (1973).

Kohn, B. P. \& Glasby, G. P. N.Z. J. Geol. Geophys. 21 49-70 (1978).

6. Watkins, N. D. \& Huang, T. C. N.Z. J. Geol. Geophys. 20, 179-198 (1977).

7. Wilson, L., Sparks, R. S. J., Huang, T. C. \& Watkins, N. D. J. geophys. Res. 83, 1829-1836 (1978).

8. Mossop, S. C. Nature 203, 824-827 (1964).

9. Hammer, C. U., Clausen, H. B. \& Dansgaard, W. Nature 288, 230-235 (1980).

10. Vucetich, C. G. \& Pullar, W. A. N.Z. J. Geol. Geophys. 16, 745-780 (1973).
WILSON ET AL. REPLY-We answer Froggatt's five objections to our interpretation $^{1}$ as follows:

(1) We accept that the red Sun, Moon and sky colouration would have been caused by the finest particles (mostly $\leqslant 0.5 \mu \mathrm{m})^{2}$ and that particles from sources other than Taupo could have been responsible. We believe that a close temporal correlation exists between optical effects recorded by Chinese and Roman historians, and a volcanic eruption which seems to be one of the outstanding explosive eruptions of the past 2 millenia. The optical phenomena are consistent with the arrival in the Northern Hemisphere of significant quantities of the finest particles from the Taupo eruption.

(2) We stand by our figure for the volume of the Taupo ultraplinian pumice-fall deposit, and cannot comment on Froggatt's estimate as we do not know its basis. However, the absolute volume of ash released to the atmosphere is much less important in determining the dispersal than the height to which the material is injected. Regarding the apparent absence of significant amounts of Taupo eruptive material in offshore sediment cores, two of the three studies quoted were in areas well north ${ }^{3}$ and well south ${ }^{4}$ of the seaward extension of the mapped dispersal axis. The third offshore study ${ }^{5}$ was centred $\geqslant 1,600 \mathrm{~km}$ downwind from source where the expected thickness of Taupo eruptive material would be $<1 \mathrm{~mm}$; because of bioturbation, such an ash layer is unlikely to survive as a discrete bed ${ }^{6,7}$.

(3) We have never claimed that the eruption column height was controlled by the eruption volume, or that $16 \mathrm{~km}^{3}$ of fine ash rose higher than $50-55 \mathrm{~km}$. However, two methods indicate that the height of the ultraplinian eruption column was $50 \mathrm{~km}$ or more (ref. 8 and L. Wilson, personal communication). Material of a grain size appropriate to cause the atmospheric effects recorded in the Northern Hemisphere, if injected to $55 \mathrm{~km}$ height, might be expected to take up to several years to fall even to $30 \mathrm{~km}$ (ref. 9) and would not fall significantly "within a few weeks". The 1963 eruption of Mt Agung was a much smaller and less violent even than the Taupo eruption; its maximum eruption column column height was only $\sim 13 \mathrm{~km}$ and the first 3 months' activity produced only $0.28 \mathrm{~km}^{3}$ of material $^{10}$.

(4) We agree that the bulk of the ash resulting from the Taupo ultraplinian phase, as well as from earlier and later explosive phases of the same eruption, would probably have been confined to the southern hemisphere. This, however, does not preclude the dispersal of significant amounts of the finest particles to the Northern Hemisphere. Regarding the 